\title{
A Lesson from Indonesia: Implementing 2006 and 2013 English Curriculum
}

\author{
Surya Fajar Cahyo Nuraeni
}

Faculty of Education, Monash University, Melbourne, Australia

\begin{abstract}
How to cite this paper: Nuraeni, S. F. C. (2018). A Lesson from Indonesia: Implementing 2006 and 2013 English Curriculum. The Educational Review, USA, 2(7), 386-396. http://dx.doi.org/10.26855/er.2018.07.003
\end{abstract}

Corresponding author: Surya Fajar Cahyo Nuraeni, Master of TESOL (candidate), Faculty of Education, Monash University, Melbourne, Australia.

\begin{abstract}
It is widely assumed that there should be one curriculum in a country to set the standards guiding the teaching and learning process. In Indonesia, however, there are two national curricula implemented at the same time, namely Curriculum 2006 and Curriculum 2013. Given the lack of studies investigating this issue, this article presents a comparative study of these two curricula focusing on English subject in the senior high school context in Indonesia. It aims at examining the distinction between 2006 English Curriculum and 2013 English Curriculum implemented and their implications for English teaching and learning practice. It is found that these two curricula are distinctive in terms of the development, underlying principles, influential factors, both stated and unstated purposes, pedagogy, and assessment carried out. The discussion concludes with a presentation of the idea of the implementation of CORE pedagogy and authentic assessment to reform the education system as well as to address the most urgent educational issue.
\end{abstract}

\section{Keywords}

English Curriculum, Curriculum Development, CORE Pedagogy, Authentic Assessment

\section{Introduction}

Since 2013, there have been two different curricula implemented at the primary and secondary education levels in Indonesia. Those are Curriculum 2006 and Curriculum 2013 in which Curriculum 2013 is a renewal of Curriculum 2006. As the latest curriculum, it has been implemented in several selected schools in Indonesia. The implementation of this curriculum, however, has become considerable debate as many question whether the schools and practitioners are ready to implement the newest curriculum. After a year of its implementation, a new Minister of Education and Culture was elected and issued a ministerial decree on curriculum evaluation to decide whether a revision is needed (Kemdikbud, 2014b). Two months later, the evaluation team found out that the teachers were lack of readiness to implement the curriculum (Kemdikbud, 2014d) and the minister issued another decree on the implementation of Curriculum 2006 and Curriculum 2013. It regulates the schools having implemented the latest curriculum for less than three semesters to terminate its implementation and implement the previous curriculum, Curriculum 2006 (Kemdikbud, 2014c). Consequently, two curricula are implemented for English subject, namely 2006 English Curriculum (EC) and 2013 English Curriculum (EC). This article will focus on the senior high school level context.

\section{Development of the Curricula}


Curriculum development is a process of "balancing act" of various stakeholders holding different views on the most meaningful content knowledge for the students (Dowden, 2013, p. 2). Resh and Bonavot (2009) conclude that school-based curriculum is designed based on the national guideline given by the central government and the teachers design its implementation in their classroom. According to Law no. 20/2003 on National Education System, curriculum framework and structure for all subjects taught at the senior high school level in Indonesia is designed by the government through the Department of Education and Culture based on the national education standards set by the National Education Standards Board (Depdiknas, 2003).

However, there are different groups involved in the development of 2006 EC and 2013 EC. While 2006 EC is developed by the Department of Education and Culture through the National Education Standards Board, English teachers, school principal, and provincial department of education (BNSP, 2006; Depdiknas, 2005; Kemdikbud, 2014a), 2013 EC is designed by the National Education Standards Board under the Department of Education and Culture, English teachers, and school principal, without participation of provincial department of education (Kemdikbud, 2014a). These indicate that the development of the curricula for English subject does not involve the students as the subjects who will experience the curricula implemented. Curriculum, by contrast, should put the students as the main stakeholder (Dowden, 2013). Also, teachers should get involved in the main process of curriculum forming as they bring their professional knowledge and experience to construct an ideal curriculum (Gobby, 2017). In fact, Bascia, Carr-Harris, Fine-Meyer, and Zurzolo (2014) point out that the teachers are often marginalised in the development of curriculum, but they are active at the implementation level. It represents what happens in the Indonesian context. It indicates that the development of English curricula in Indonesia is partially decentralised that does not give much power to the local government or teachers and school principal to collaboratively design the curriculum they need in accordance with the students and school's needs.

There is a noticeable difference in how each curriculum is developed. The first step of the development of 2006 EC is that the National Education Standards Board issue a set of expected learning outcomes of English subject based on the national education goals (BNSP, 2006; Depdiknas, 2005; Kemdikbud, 2014a). Then, it is broken down into the standard of teaching and learning process, learning objectives, and assessment in the form of general guideline issued by the National Education Standards Board (BNSP, 2006; Depdiknas, 2005; Kemdikbud, 2014a). After that, the teachers and school principal work collaboratively to identify the course objectives and the students and school's needs to design English syllabus, lesson plan, assessment, and student's book under the supervision of the provincial department of education (BNSP, 2006; Depdiknas, 2005; Kemdikbud, 2014a). On the contrary, 2013 EC development is begun with analysis of the students' readiness and national educational goals and needs done by the National Education Standards Board to form expected learning outcomes of each education level (Kemdikbud, 2014a). Then, they construct curriculum framework and structure and break it down into standards of teaching and learning process, learning objectives, and assessment that become the basis of syllabus (Kemdikbud, 2014a). Next, they provide the teachers with syllabus, teacher's book, and student's book (Kemdikbud, 2014a). After that, the teachers and school principal work on lesson plan, learning process and assessment, and supplementary book (Kemdikbud, 2014a). Generally, those curricula are similarly introduced through socialisation programs in forms of workshops and assistance programs (Depdiknas, 2006b; Kemdikbud, 2014a). These are held by the Department of Education and Culture in collaboration with provincial and local department of education and intended for the teachers, headmasters, and supervisors from local government (Depdiknas, 2006b; Kemdikbud, 2014a). This is significant as they play a key role in making a decision on how the curriculum is implemented (Gobby, 2017). Thus, it is believed that without considering the practitioners who will implement the curriculum, the intended purposes will not be achieved.

\section{Educational Philosophies and Implicit Cultural Norms and Values}


Underpinned by the national educational philosophy combined with cultural norms and values, these two English curricula have different unstated purposes. On one hand, the idea of addressing diversity among society has a considerable effect on 2006 EC (Prastiwi, 2013). Implicitly, there are three unstated purposes of this curriculum. Firstly, it aims at developing the students' sense of belonging to the local culture, including its norms and values. Secondly, it is intended to teach the students cultural awareness and diversity. Moreover, it is implicit to preserve the local culture while learning another language and culture. In $2006 \mathrm{EC}$, the use of local folklore as the learning resources, for example, is without no intention (Prastiwi, 2013). It tacitly builds the students' awareness of their own culture and cultural diversity. Furthermore, this is a form of government's way to reject the assumption saying that learning a foreign language will possibly make the students lose their cultural identity. In fact, this 2006 EC gives the students opportunities to embrace the concept of "unity in diversity", a motto of Indonesian multicultural society. Later, it will grow the students' strong sense of nationality (Prastiwi, 2013). It shows how 2006 EC addresses the issues of language, culture, and identity while learning a new language.

On the other hand, 2013 EC is broadly affected by the idea of reforming the students' character and behaviour to prepare them for their active participation in the society. Habeahan (2017) believes that strengthening the position of national ideology, Pancasila, is an implicit purpose of this curriculum. First, it is reflected in two core competences related to religion and behaviour in 2013 EC. This allows moral and religious values to be embedded in this curriculum (Ahmad, 2014; Hapsari, 2013). They are indirectly employed in the teaching and learning activities implemented 2013 EC. For instance, in order to strengthen the students' Islamic identity, the teachers open and end the teaching and learning activities by praying and greeting (Isa, 2016). This shapes the students to be deeply religious, the first value of Pancasila. Secondly, 2013 EC expects the teachers to promote collaborative learning in the teaching and learning process (Kemdikbud, 2016a). This is not merely a matter of enhancing their communication skills using the language learned, but it is a way to foster the students' soft skills to be able to work cooperatively and respect other people in their community which is the second value of Pancasila. This implies that values of Pancasila are implicitly brought to the classroom. It aims at growing the students' awareness of the values of national ideology to be adapted as the society norms and values (Habeahan, 2017). This enables the government to indirectly build the future citizen's characters to behave accordingly in the society based on the values mandated by the ideology.

These different unstated purposes of these two curricula show how the government address cultural and social issues among the society. Tedesco, Opertti, and Amadio (2014, p. 2) argue that education framework within the curriculum is to "provide a more effective response to the expectations and demands of youth and society". It is also clear that the curriculum is developed "to address challenges and daily life situations" (Tedesco et al., 2014, p. 44). In particular, a significant function of curriculum is to improve human well-being (Pratt, 1994). These ideas are reflected in those unstated purposes of both 2006 EC and 2013 EC that are different based on the social and cultural challenges when those curricula are implemented. Besides, it implies that those curricula function their roles to provide the students with relevant learning experiences to reform the society and raise their awareness of diversity (Tedesco et al., 2014). Since there is no intended teaching method nor strategies brought by both curricula to achieve these implicit objectives, these can be classified as a part of hidden curriculum within the implementation of both English curricula. Kentli (2009) and Wilson (n.d.) highlight hidden curriculum as an implicit message the students get from any form of social interaction in their school about values, attitudes, norms, and principles. Therefore, although they are not stated, the students are possibly able to get these unstated messages through their learning experience.

\section{Broad Influences on the Curricula}

These two English curricula are influenced by economics and politics. Economic dimension has a great influence on the curriculum to prepare the students for career opportunities and market demand (Brady \& Kennedy, 201 4; Gobby, 2017). Both 2006 EC and 2013 EC are designed by considering the industry's expectation from graduates. However, the cases are consid- 
erably different. On one hand, 2006 EC is influenced by the industry demand for job-ready graduates (Depdiknas, 2006a). This encourages the government to design the curriculum that serves the students with not only knowledge but also ability to put the knowledge into practices. Consequently, reforming grammar translation method with teaching integrated skills in English classes is a deliberate decision to develop the students' oral and written language competencies needed in the workplace (BNSP, 2007). It exemplifies how economics affect 2006 EC. On the other hand, 2013 EC is broadly influenced by the raise of creative industry and the participation of Indonesia in ASEAN Free Trade Area (AFTA) that demand the graduates to have skills and competences to be ready for the job competition, in both local and global scope (Kemdikbud, 2013; Kemdikbud, 2014a).

As the graduates' English proficiency is still low (Lie, 2007), the government revised the 2006 EC with 2013 EC. This curriculum focusses on improving the students' communicative skills by designing teaching and learning process covering four language skills. Those are listening, reading, speaking, and writing taught by applying an inductive approach that place the students at the centre of learning. For instance, communicating becomes one stage within the current teaching approach to offer the students opportunities to demonstrate the language learned (Kemdikbud, 2016a). This is identified as an effective teaching practice to cultivate English skills needed for the job market. Primarily, Lie (2007) argues that the teaching of English in Indonesia is affected by the society assumption that English proficiency is an essential point to get a secure position in the job market. This makes the government, particularly the Department of Education and Culture, evaluate the English curriculum to see how well the students develop their English proficiency under the curriculum implemented through the national standardised test. This is an influential factor affecting the government decision to revise the curriculum to serve the students with better learning opportunities. Finally, this is intended to improve their English skills that will be valued in the job competition.

Another factor influencing the curriculum development is political power. Resh and Benavot (2009) believe that curriculum development and implementation are broadly influenced by political conditions including centralisation and educational conservatism. $2006 \mathrm{EC}$ is affected by the idea of decentralisation in government. As a democracy barometer, decentralisation of decision-making is created through the way that the central government give the local government authority to distribute the function and power. This becomes the main reason why the Department of Education and Culture give the provincial department of education authority to participate in the curriculum development process to consider their local culture and wisdom and their local needs (Depdiknas, 2006a). This gives the provincial department an opportunity to identify what norms and values they will include in the curriculum to accommodate the society's needs without being dictated by the central government.

In contrast, 2013 English Curriculum is greatly influenced by the changing of the Indonesian cabinet formation (Ilma \& Pratama, 2015; Muth'im 2014). It is believed that the changing of the curriculum, from Curriculum 2006 to Curriculum 2013, including the EC is resulted from the changing of the Minister of Education and Culture. A proof of political influence over 2013 EC is that when the teaching approach was changed from Genre-Based Approach (GBA) to Scientific Approach (SA) after a new Minister of Education and Culture was elected. In fact, a comprehensive evaluation of the previous approach is needed before this reform. Mubarak (2017) suggests that the changing of the curriculum has to be based on the educational philosophy underlying the curriculum, instead of political interest of the minister to create a history of his leadership. In fact, the power of politics is a dominant domain shaping the curriculum (Gobby, 2017). Political interests are possibly brought to the development of curriculum (Apple, 1993). In addition, there is a tendency for the newly elected minister for a crisis of trust to the previous minister (Mubarak, 2017). This directly affects the English curriculum in Indonesia.

\section{Purposes of the Curricula}

\subsection{Stated Purposes of the Curricula}


According to the curriculum guideline, Curriculum 2006 aims at developing the students' cognitive skills, shaping their character and behaviour, improving their skills to be independent citizen, and preparing them for pursuing higher education (BNSP, 2006). In line with the general goal, $2006 \mathrm{EC}$ is intended to develop the students' literacy skills to certain functional level that they can access the knowledge using the language learned and as a preparation for the university level (Depdiknas, 2006a). It implies that the curriculum focusses more on developing their ability to comprehend and communicate both oral and written information in English rather than character building. Meanwhile, the goal of Curriculum 2013 is to prepare the students to be religious, productive, creative, innovative, and well-mannered citizen that will be able to positively contribute to the society, country, and global community (Kemdikbud, 2013). In particular, 2013 EC's objectives are set into four core competences. Those are valuing and demonstrating their religious belief, valuing and demonstrating honesty, discipline, responsibility, care, politeness, responsiveness, and proactive approach in the social interaction representing the character of Indonesian citizen in the global community, understanding and implementing knowledge of language learned based on their interests, and comprehending and communicating the knowledge in the real life (Kemdikbud, 2013). However, clear guidance on how to achieve the first two core competences is needed.

Overall, both 2006 and 2013 curriculum put the students' character development and language proficiency improvement as the two main concerns. It clearly shows how curricula can provide the government with a tool to improve the educational outcomes (Gobby, 2017). However, when it comes to the English curricula, it is noticeable that 2006 EC only aims at developing the students' English skills. On the contrary, the latest one makes development of the students' character and English communication skills as the purposes. Thus, it is essential for the teachers to analyse the objectives of each curriculum implemented to design the most appropriate method to help the students achieve the intended learning outcomes (Willis \& Kissane, 1995, in Marsh, Clarke, \& Pittaway, 2014).

\subsection{Unstated Purposes of the Curricula}

Both 2006 and 2013 EC are developed based on the Law No. 20/2003 on National Education Standards. It is stated that the national education is a way to raise a religious, well-mannered, and productive citizen equipped with developed skills and competences (Depdiknas, 2003). It indicates that the national education goal is influenced by progressivism and reconstructionism, two main educational philosophies. While progressivism aims at promoting a democratic social life by providing active learning, reconstructionism is intended to reform the society (Hanif, 2014; Ornstein, 1990). These educational philosophies function as a basis directing the curriculum development (Ekanem \& Ekefre, 2014; Ornstein, 1990). Generally, this reinforces the idea of providing the students with opportunities to learning to live together. Implicitly, national education has to value religious belief, cultural values, and diversity among society in Indonesia (Depdiknas, 2003). Because of that, the teaching and learning process implementing $2006 \mathrm{EC}$ has to address cultural diversity in local scope. This encourages the teachers to adjust the teaching and learning resources with the culture and values from the local community, for example by using Indonesian folklore (Prastiwi, 2013). This enables the teachers to teach English skills and local culture at the same time (Prastiwi, 2013). In order to value the diversity, this curriculum gives an autonomy to the provincial department of education to collaborate with the teachers and school principal to identify their own local culture when designing the syllabus and lesson plan (Sujana, Nuryanti, \& Narasintawati, 2010). This "educational decentralisation" will create both school autonomy and "curricular diversification" (Resh \& Bonavot, 2009, p. 67).

Meanwhile, 2013 English Curriculum is designed by considering several social and behavioural problems in the society, from students misbehave to civil unrest (Kemdikbud, 2014a). This underlies the government decision to integrate moral values in the teaching of English to shape the students' character to reform the future society (Hapsari, 2013). It is an indicator showing that cognitive aspect is not the only concern in this curriculum. It is reflected in four core competences which are course objectives the 
students are expected to achieve. Those are religion, behaviour, knowledge, and skills (Kemdikbud, 2013). By considering these domains in the teaching and learning process in all subjects taught, including English, the students' behaviour will be shaped to behave accordingly in the society. In general, progressivism and reconstructionism broadly influence the national education goal and form these two curricula. Further, cultural norms and values underlie the purposes of these different curricula.

\section{Attitudes toward the Implementation of the Curricula}

English teachers, academics, and students give different reactions towards 2006 EC and 2013 EC. On 2006 EC, the teachers still need more exposure to understand its implementation and the senior teachers tend not to adapt their teaching style to the teaching approach in the new curriculum (Ratri \& Yuliana, 2010, in Diem, Yusfardiyah, Koniaturrohmah, \& Lismalayani, 2016). They are comfortable with their teacher-centred teaching practices. Also, they find it difficult to teach integrated skills and perceive lecturing as the most applicable teaching method in their classes (Diem et al., 2016). Teaching innovation will not bring any impact when it is not implemented in the classroom (Cohen, 1990). Besides, this is caused by their changing role, from user to designer of the curriculum implemented (Sujana et al., 2010). However, the teachers participating in socialisation programs show positive attitudes towards $2006 \mathrm{EC}$ since they understand how to implement the curriculum and create studentcentred learning activities with innovative teaching method, media, and learning sources (Putri, 2016). Academics, additionally, believe that the curriculum renewal is relevant as it adju sts the content knowledge and learning objectives to current situation (Mahfuddin, 2013). On the other hand, the students find the teaching and learning process still text-book oriented and teachercentred that gives them insufficient opportunities for language practice (Nur \& Madkur, 2014).

Similarly, the teachers, academics, and students show different attitudes towards the implementation of 2013 EC. Some teachers are not sure about their own readiness to implement the latest curriculum, including the new teaching approach, as they get used to teach using the existing teaching methods (Fajrianti, Yufrizal, \& Supriady, 2014). Meanwhile, others support this curriculum since the teaching approach implemented is helpful to develop the students' critical thinking and enable the teachers to focus on the students' cognitive and affective aspects (Nur \& Madkur, 2014). Their perceptions can be enhanced when they participate in the curriculum construction. Marsh et al. (2014) argue that the teachers' involvement in designing the curriculum increases their responsibility for curriculum decision making that affects their views. Likewise, this latest curriculum is supported by some academics as it covers not only intelligence but also behaviour that benefit the students (Fajrianti et al., 2014). Fajrianti et al.'s (2014) study also reveals the students' positive attitudes towards the teaching and learning process implementing $2013 \mathrm{EC}$ as it is more engaging.

\section{Pedagogy Implied by the Curricula}

The focus of $2006 \mathrm{EC}$ at the high school level is on the development of language skills, including its linguistic and socialcultural competences (Mattarima \& Hamdan, 2011). In general, the teaching and learning process enables the students to develop their listening, reading, speaking, and writing skills (Depdiknas, 2006b). The main teaching and learning activities are structured into three phases which are exploration, elaboration, and confirmation (BNSP, 2007). This aims at encouraging the students to actively participate during learning process. In addition, GBA is implemented in the teaching and learning process to improve the students' communicative skills (Diem et al., 2016; Tartila, Yasin, \& Rozimela, 2013). It supports the teachers to give the students background knowledge of language skill, modelling of skill learned, and opportunity to collaboratively practice the skill before independent practice. However, the implementation is still teacher-centred involving drillings to make the students understand the learning materials (Mattarima \& Hamdan 2011; Tartila et al., 2013). Also, the teachers focus more 
on the written form than spoken form (Putra, 2014, p. 69). As a result, the students lack opportunities for language practice. Moreover, four hours learning English per week does not provide the students with adequate exposure to the language learned (Mattarima \& Hamdan 2011).

Conversely, 2013 EC reforms the teaching and learning process to be enjoyable, contextual, and communicative based on five stages of SA consisting of observing, questioning, experimenting, associating, and communicating (Kemdikbud, 2016a). This inductive approach guides the students to actively discover the language structure and practice it in written and oral forms. It is good teaching when the students actively construct the knowledge (Haberman, 1991). The students can benefit from this way of learning. However, it disadvantages them when the teachers do not reform their pedagogy. Besides, Putra (2014) identifies that the absolute authority of the Department Education and Culture to design the syllabus and distribute to the teachers will create gap between students in the cities and rural areas. Additionally, limited educational budget results in inadequate learning facilities in many public schools (Lie, 2007). Also, the students have different access to learning resources. Privileged students find it easy to access any resources to de velop their English outside classroom while the less privileged ones depend their language development on the classroom teaching and learning process (Lie, 2007). Another problem is due to the reduction of time allotment from four hours to three hours per week leading the students to lack of English exposure (Putra, 2014). Without sufficient exposure, the students' English skills will hardly be improved as the amount of exposure to the language learned is one of the influential factors affecting the students' success in learning the language.

\section{Assessment Carried out by the Curricula}

In order to assess the students' learning progress, both English curricula use the same types of formative and summative as sessment. Quiz, observation, and project are forms of formative assessment while midterm examination and final examination are for summative assessment done every semester (Depdiknas, 2007; Kemdikbud, 2016b). In addition, there are two summative assessment forms for the twelfth graders, namely English school-based final examination designed by the teachers in their schools and English National Examination (ENE) set by the Department of Education and Culture through the National Education Standards Board (Depdiknas, 2007; Kemdikbud, 2016b). It indicates that there is an equal proportion between formative and summative assessment sharing the authority of the teachers and central government. In addition, religion, attitudes, knowledge, and skills are aspects covered in assessment in 2013 EC (Kemdikbud, 2016b). However, most of the assessment practices only assess the students' cognitive aspect. Also, the practice of ENE arouses controversy in assessment practice of these two EC since the same assessment is used regardless the different curricula implemented. Thus, it is doubtful whether this examination could assess the students' English competences since the different curricula have different learning focus. While students' knowledge of English is the focus of 2006 EC, 2013 EC put the students' English communication skills in the centre of the teaching and learning process (Putra, 2014). This assessment practice only benefits the government, particularly the Ministry of Education and Culture as this national standardised test is a quick and effective way pro viding them with the data to evaluate the national education quality. Conversely, it disadvantages the teachers and students. Firstly, this high-stake test makes the teacher teach for the test covering listening and reading skills only (Furaidah, Saukah, \& Widiati, 2015; Lie, 2007; Sukyadi \& Mardiani, 2011). In addition, it is unfair for the students to take the same test regardless different curricula they experience (Putra, 2014; Depdiknas, 2007; Kemdikbud, 2016b). Also, they find it frustrating as this paper-based test consisting of listening and reading questions becomes the determinant of their three years of learning (Sukyadi \& Mardiani, 2011). Moreover, this multiple-choice test only assesses the students' discrete linguistic skills. It is insufficient to assess the students' communicative skills and integrated language skills (Amini \& Gonzales, 2012). As a consequent, the result could not really reflect the students' English competence (Kim, 2012; Putra, 2014; Sukyadi \& Mardiani, 2011). This also reflects Eisner's (2000) finding that many assessment practices are not aligned with the intended learning outcomes. 


\section{Conclusion and Implications}

This comparative study of two English curricula raises the awareness of the needs for reforming curriculum in the Indonesian education context, particularly EC. This study, in addition, provides us with both theoretical and practical implications. Theoretically, this discussion carried out by this study will enrich the literature reviewing both differences and similarities among $2006 \mathrm{EC}$ and $2013 \mathrm{EC}$ at the senior high school level. At the practical level, this study gives policy makers some constructive suggestions for the better development and implementation of the curriculum. It is significant to consider the roles of both the teachers and students in the first stage of the curriculum development. As the main subjects of the curriculum, the policy makers should include them not only in the implementation but also in the development phase. Their insights and ideas are valuable for the development of ideal and relevant curriculum. This will reform the status of the teachers and students that they are the subjects of the curriculum, instead of the objects of the education system. Additionally, it is needed to propose a pedagogy that effectively encourages the students to actively participate in the learning process. CORE pedagogy proposed by Zyngier (2008) possibly meets this objective as it is connecting, owning, responding, and empowering the students to create engagement with learning process. Also, it is essential for the policy makers to reform the assessment policy by eliminating ENE due to its low reliability and validity that disadvantages both the students and teachers. Besides, it is important to align the assessments with the curriculum implemented to form meaningful assessment focusing on improving the students learning (McConnell \& Doolittle, 2011). As an alternative to the ENE, classroom-level assessment using authentic assessment can be proposed by considering its functions as formative and summative assessment (Black \& Wiliam, 2005). Moreover, the teachers should consider embedding CORE pedagogy in the teaching approach to create meaningful learning for the students, aligning assessment with pedagogy practices, and putting theories into practices. Finally, other further studies can be drawn on challenging educational policies, particularly curriculum, pedagogy, and assessment to reform the Indonesian education system and create an alignment among those elements.

\section{References}

Ahmad, D. (2014). Understanding the 2013 Curriculum of English Teaching through the Teachers' and Policymakers' Perspectives. International Journal of Enhanced Research in Educational Development, 2(4), 6-15. Retrieved from http://www.erpublications.com/uploaded_files/download/download_25_07_2014_16_32_27.pdf

Amini, M. \& Gonzales, N. I. (2012). The Washback Effect of Cloze and Multiple Choice Tests on Vocabulary Acquisition. Language in India, 12(7), 71-91. Retrieved from http://www.languageinindia.com/july2012/aminibackwashfinal.html

Apple, M. W. (1993). The Politics of Official Knowledge: Does a National Curriculum Make Sense? Discourse: Studies in the Cultural Politics of Education, 14(1), 1-16. doi: 10.1080/0159630930140101

Bascia, N., Carr-Harris, S., Fine-Meyer, R., \& Zurzolo, C. (2014). Teachers, Curriculum Innovation, and Policy Formation. Curriculum Inquiry, 44(2), 228-248. doi:10.1111/curi.12044

Black, P. \& Wiliam, D. (2005). Lessons from around the World: How Policies, Politics and Cultures Constrain and Afford Assess ment Practices. The Curriculum Journal, 16(2), 249-261. doi: 10.1080/09585170500136218

BNSP. (2006). Panduan Penyusunan Kurikulum Tingkat Satuan Pendidikan Jenjang Pendidikan Dasar dan Menengah [Guideline on the Development of School-based Curriculum for Primary and Secondary Education Level]. Retrieved from http://bsnp-indonesia.org/wpcontent/uploads/kompetensi/Panduan_Umum_KTSP.pdf

BNSP. (2007). Peraturan Menteri Pendidikan Nasional Republik Indonesia no. 41/2007 tentang Standar Proses untuk Satuan Pendidikan Dasar dan Menengah [Decree of Ministry of National Education of Republic of Indonesia no. 41/2007 on Process Standards for Primary and Secondary Education Level]. Retrieved from http://wbgfiles.worldbank.org/documents/hdn/ed/saber/supporting_doc/ EAP/Teachers/Indonesia/Permen_41_Th-2007.pdf

Brady, L. \& Kennedy, K. J. (2014). Curriculum Construction (5th Ed.). Frenchs Forest, NSW: Pearson Australia.

Cohen, D. K. (1990). A Revolution in One Classroom: The Case of Mrs. Oublier. Educational Evaluation and Policy Analysis, 12(3), 311-329. doi: 10.3102/01623737012003311

Depdiknas. (2003). Undang-Undang Republik Indonesia no. 20/2003 tentang Sistem Pendidikan Nasional [Law no. 20/2003 on National Education System]. Retrieved from http://peraturan.go.id/uu/nomor-20-tahun-2003.html 
Depdiknas. (2005). Peraturan Pemerintah Republik Indonesia no. 19/2005 tentang Standar Nasional Pendidikan [Government of Republic of Indonesia Regulation no. 19/2005 on National Education Standards]. Retrieved from https://kemenag.go.id/file/dokumen/PP1905.pdf

Depdiknas. (2006a). Peraturan Menteri Pendidikan Nasional Republik Indonesia no. 22/2006 tentang Standar Isi untuk Satuan Pendidikan Dasar dan Menengah [Decree of Ministry of National Education of Republic of Indonesia no. 22/2006 on Content Standards for Primary and Secondary Education Level]. Retrieved from https:/www.academia.edu/19822754/Permendiknas-no-22-tahun-2006-standar-isi

Depdiknas. (2006b). Peraturan Menteri Pendidikan dan Kebudayaan Republik Indonesia no. 24/2006 tentang Pelaksanaan Peraturan Menteri Pendidikan Nasional no. 22/2006 tentang Standar Isi untuk Satuan Pendidikan Dasar dan Menengah dan Peraturan Menteri Pendidikan Nasional no. 23/2006 tentang Standar Kompetensi Lulusan untuk Satuan Pendidikan Dasar dan Menengah [Decree of Ministry of National Education of Republic of Indonesia no. 22/2006 on Content Standards for Primary and Secondary Education Level and Decree of Ministry of National Education of Republic of Indonesia no. 23/2006 on Graduate Competency Standards for Primary and Secondary Education Level]. Retrieved from http://simpuh.kemenag.go.id/regulasi/permendiknas_24_06.pdf

Depdiknas. (2007). Peraturan Menteri Pendidikan Nasional no. 20/2007 tentang Standar Penilaian Pendidikan [Decree of Ministry of National Education no. 20/2007 on Assessment $\quad$ Standards]. Retrieved http://www.sman4bukittinggi.sch.id/media/pp_dan_permen/Permendiknas20-2007StandarPenilaian.pdf

Diem, C. D., Yusfardiyah, Koniaturrohmah, B., \& Lismalayani. (2016). Implementation of School-based Curriculum as Perceived by Secondary School Teachers of English. Indonesian Journal of Applied Linguistics, 5(2), 167-175. doi: 10.17509/ijal.v5i2.1341

Dowden, T. (2013). Understanding the Curriculum. In P. Hudson (Ed.), Learning to Teach in the Primary School (pp. 37-51). Melbourne, VIC: Cambridge University Press.

Eisner, E. W. (2000). Those who Ignore the Past ... : 12 'Easy' Lessons for the Next Millennium. Journal of Curriculum Studies, 32(2), 343-357. doi: 10.1080/002202700182808

Ekanem, S. A. \& Ekefre, E. N. (2014). Philosophical Foundation of Curriculum Development in Nigeria: The Essencist Model. Journal of Educational and Social Research, 4(3). doi: 10.5901/jesr.2014.v4n3p265

Fajrianti, D., Yufrizal, H., \& Supriady, D. (2014). Analyzing Students' Perception on 2013 Curriculum Implementation in English Teaching Learning Process. U-JET, 3(7), 1-15. Retrieved from http://jurnal.fkip.unila.ac.id/index.php/123/article/view/6246

Furaidah, Saukah, A., \& Widiati, U. (2015). Washback of English National Examination in the Indonesian Context. TEFLIN Journal, 26(1), 36-58. doi: 10.15639/teflinjournal.v26i1/36-58

Gobby, B. (2017). What is Curriculum?. In B. Gobby \& R. Walker (Eds.), Powers of Curriculum Sociological Perspectives on Education (pp. 5-34). Melbourne, VIC: Oxford University Press.

Habeahan, S. (2017). Penguatan Nilai-Nilai Karakter Pancasila di Sekolah melalui Kurikulum 2013 [Strengthening the Values of Pancasila in the Schools Implementing Curriculum 2013]. Retrieved http://www.netralnews.com/news/opini/read/80767/penguatan.nilai.nilai.karakter.pancasila.di.sekolah.melalui.kurikulum.2013

Haberman, M. (1991). The Pedagogy of Poverty versus Good Teaching. The Phi Delta Kappan, 73(1), 290-294. Retrieved from http://www.jstor.org/stable/20404620

Hanif, M. (2014). Tinjauan Filosofis Kurikulum 2013 [Analysis of Educational Philosophies of Curriculum 2013]. Insania, 19(1), 87-114. Retrieved from https://media.neliti.com/media/publications/73902-ID-tinjauan-filosofis-kurikulum-2013.pdf

Hapsari, A. (2013, August). Making Sense the Character Building in the Curriculum Framework: Conceptualizing Culture as a Local Wisdom and Culture as the Product of Interaction. Paper presented at the $60^{\text {th }}$ TEFLIN International Conference: Achieving International Standards in Teacher Education, Jakarta Indonesia. Retrieved from http://astri.staff.uii.ac.id/2013/09/10/making-sense-the-character-buildingin-the-curriculum-framework-conceptualizing-culture-as-a-local-w isdom-and-culture-as-the-product-of-interaction/

Ilma, Z. \& Pratama, R. K. (2015, March). Transformation in Indonesian Language Curriculum: Pros and Cons between KTSP 2006 and Curriculum 2013 in Indonesia. Presented at International Conference on Trends in Economics, Humanities and Management, Singapore. Retrieved from http://icehm.org/upload/5097ED0315007.pdf

Isa, Q. N. M. (2016, October). Pengintegrasian Nilai Islami dalam Pelaksanaan Simulasi Pembelajaran Bahasa Inggris oleh Mahasiswa Micro Teaching Prodi Pendidikan Bahasa Inggris FTK UIN Ar-Raniry [Integrating Islamic Values in the Teaching of English by Micro Teaching Participants Majoring English Education of UIN Ar-Raniry]. Paper presented at the $1{ }^{\text {st }}$ Ar-Raniry International Conferene on Islamic Studies, Banda Aceh Indonesia. Retrieved from http://jurnal.ar-raniry.ac.id/index.php/aricis/article/view/938/745

Kemdikbud. (2013). Peraturan Menteri Pendidikan dan Kebudayaan Republik Indonesia no. 69/2013 tentang Kerangka Dasar dan Struktur Kurikulum Sekolah Menengah Atas/Madrasah Aliyah [Decree of the Ministry of Education and Culture of Republic of Indonesia no. 69/2013 on the Curriculum Framework and Structure for Senior High Schools]. Retrieved from http://biologi.fkip.uns.ac.id/wpcontent/uploads/2013/08/PDK-2013-69-Kerangka-Dasar-Kurikulum-Kompetensi-SMA.pdf

Kemdikbud. (2014a). Konsep dan Implementasi Kurikulum 2013 [Concept and Implementation of Curriculum 2013]. Retrieved from https://kemdikbud.go.id/kemdikbud/dokumen/Paparan/Paparan\%20Wamendik.pdf 
Kemdikbud. (2014b). Peraturan Menteri Pendidikan dan Kebudayaan Republik Indonesia no. $159 / 2014$ tentang Evaluasi Kurikulum [Decree of the Ministry of Education and Culture of Republic of Indonesia no. 159/2014 on the Curriculum Evaluation]. Retrieved from http://simpuh.kemenag.go.id/regulasi/permendikbud_159_14.pdf

Kemdikbud. (2014c). Peraturan Menteri Pendidikan dan Kebudayaan Republik Indonesia no. 160/2014 tentang Pemberlakuan Kurikulum 2006 dan Kurikulum 2013 [Decree of Ministry of Education and Culture of the Republic of Indonesia no. 160/2014 on the Implementation of Curriculum 2006 and Curriculum 2013]. Retrieved from http://dikdas.kemdikbud.go.id/wp-content/uploads/2014/12/Permendikbud-No-160Tahun-2014.pdf

Kemdikbud. (2014d). Surat Keputusan Menteri Pendidikan dan Kebudayaan Republik Indonesia no. 179342/MPK/KR/2014 tentang Pelaksanaan Kurikulum 2013 [Decree of Ministry of Education and Culture of Republic of Indonesia no. 179342/MPK/KR/2014 on the Implementation of Curriculum 2013]. Retrieved from http://pemerintah.net/surat-penghentian-kurikulum-2013

Kemdikbud. (2016a). Peraturan Menteri Pendidikan dan Kebudayaan Republik Indonesia no. 22/2016 tentang Standar Proses Pendidikan Dasar dan Menengah [Decree of Ministry of Education and Culture of Republik of Indonesia no. 22/2016 on Process Standards for Primary and Secondary Education Level]. Retrieved from http://bsnp-indonesia.org/wpcontent/uploads/2009/06/Permendikbud_Tahun2016_Nomor022_Lampiran.pdf

Kemdikbud. (2016b). Peraturan Menteri Pendidikan dan Kebudayaan Republik Indonesia no. 23/2016 tentang Standar Penilaian Pendidikan [Decree of the Ministry of Education and Culture of Republic of Indonesia no. 23/2016 on Assessment Standards]. Retrieved from http://bsnp-indonesia.org/wp-content/uploads/2009/09/Permendikbud_Tahun2016_Nomor023.pdf

Kentli, F. D. (2009). Comparison of Hidden Curriculum Theories. European Journal of Educational Studies, 1(2), 83-88. Retrieved from https://pdfs.semanticscholar.org/7b6d/7275c2c3f5f176ee42d8e661ebdb4683e959.pdf

Kim, S. (2012). Options in a Multiple-Choice English Test: Quality over Quantity. Korean Journal of English Language and Linguistics, 12(1), 19-39. doi: 10.15738/kjell.12.1.201203.19

Lie, A. (2007). Education Policy and EFL Curriculum in Indonesia: Between the Commitment to Competence and the Quest for Higher Test. TEFLIN Journal, 18(1), 1-14. Retrieved from http://teflin.org/journal/index.php/journal/article/viewFile/48/53

Mahfuddin, H. A. (2013). Kurikulum Tingkat Satuan Pendidikan (KTSP) Sekolah Menengah Atas (SMA) [School-Based Curriculum for Senior High School]. Allemania, 2 (2), 152-158. Retrieved from https://www.academia.edu/3405910/KURIKULUM_TINGKAT_SATUAN_ PENDIDIKAN_KTSP_SEKOLAH_MENENGAH_ATAS_SMA_

Marsh, C. J., Clarke, M., \& Pittaway, S. (2014). Marsh's Becoming a Teacher (6th Ed.). Frenchs Forest, NSW: Pearson Australia.

Mattarima, K. \& Hamdan, A. R. (2011). The Teaching Constraints of English as a Foreign Language in Indonesia: The Context of School Based Curriculum. Sosiohumanika, 4(2), 287-300. Retrieved from ejournal.unp.ac.id/index.php/elt/article/download/4593/3633

McConnell, K. D. \& Doolittle, P. E. (2011). Classroom-Level Assessment: Aligning Pedagogical Practices to Enhance Student Learning . In C. Secolsky \& D. B. Denison (Eds.), Handbook on Measurement, Assessment, and Evaluation in Higher Education (pp. 15-30). New York, NY: Routledge.

Mubarak, Z. (2017). Mental "Ganti Menteri Ganti Kebijakan" di Negeri Kita [Notion of "A Reform Carried out by the New Minister" in our Country]. Retrieved https://www.kompasiana.com/zakimu79/mental-ganti-menteri-ganti-kebijakan-di-negeri-kita_594326d591fdfd9f 54919572

Muth'im, A. (2014). Understanding and Responding to the Change of Curriculum in the Context of Indonesian Education. American Journal of Educational Research, 2(11), 1094-1099. doi: 10.12691/education-2-11-15

Nur, M. R. \& Madkur, A. (2014). Teachers' Voices on the 2013 Curriculum for English Instructional Activities. IJEE, 1(2), 119-133. Retrieved from http://journal.uinjkt.ac.id/index.php/ijee/article/view/1340

Ornstein, A. C. (1990). Philosophy as a Basis for Curriculum Decisions. The High School Journal, 74(2), 102-109. Retrieved from https://www.jstor.org/stable/40364829?seq=1\#page_scan_tab_contents

Prastiwi, Y. (2013). Transmitting Local Cultural Knowledge through English as Foreign Language (EFL) Learning as a Means of Fostering "Unity in Diversity". Academic Journal of Interdisciplinary Studies, 2(3). doi: 10.5901/ajis.2013.v2n3p507

Pratt, D. (1994). Curriculum Planning: A Handbook for Professionals. Fort Worth, TX: Harcourh Brace College Publishers.

Putra, K. A. (2014). The Implication of Curriculum Renewal on ELT in Indonesia. PAROLE: Journal of Linguistics and Education, 4(1), 6375. Retrieved from http://ejournal.undip.ac.id/index.php/parole/article/view/6315

Putri, A. (2016). Teachers' Perceptions toward the Implementation of School-Based Curriculum (SBC) in Indonesia. Rangsit Journal of Educational Studies, 3(1), 41-47. doi: 10.14456/rjes.2016.3

Resh, N. \& Benavot, A. (2009). Educational Governance, School Autonomy, and Curriculum Implementation: Diversity and Uniformity in Knowledge Offerings to Israeli Pupils. Journal of Curriculum Studies, 41(1), 67-92. doi: 10.1080/00220270802446826

Sujana, I. M., Nuryanti, T., \& Narasintawati, L. S. (2010). Landasan Filosofi dan Teoritis Standar Isi Bahasa Inggris dalam KTSP dan Tantangan Kurikulum LPTK Bahasa Inggris [Educational Theories and Philosophies on Content Standard of School-based Curriculum and Challenges Faced by English Department in University level]. Jurnal Linguistik, Sastra, dan Budaya (Lisdaya), 6(1), 1-15. Retrieved from 
https://www.researchgate.net/publication/315643093_I_M_LANDASAN_FILOSOFI_DAN_TEORITIS_STANDAR_ISI_BAHASA_ INGGRIS_DALAM_KTSP_DAN_TANTANGAN_KURIKULUM_LPTK_BAHASA_INGGRIS

Sukyadi, D. \& Mardiani, R. (2011). The Washback Effect of the English National Examination (ENE) on English Teachers' Classroom Teaching and Students' Learning. K@ta, 13(1), 96-111. doi: 10.9744/kata.13.1.96-111

Tartila, Yasin, A., Rozimela, Y. (2013). The Implementation of Genre Based Approach in English Teaching at Islamic Senior High School Model (MAN Model) Jambi. Journal English Language Teaching, 1(3), 36-49. Retrieved from ejournal.unp.ac.id/index.php/elt/article/download/4593/3633

Tedesco, J. C., Opertti, R., \& Amadio, M. (2014). The Curriculum Debate: Why It Is Important Today. Prospects: Quarterly Review of Comparative Education, 44(4), 527-546. doi: 10.1007/s 11125-014-9326-x

Wilson, L. O. (n.d.). Types of Curriculum: Definitions of the Different Types of Curriculum. Retrieved from http://thesecondprinciple.com/instructional-design/types-of-curriculum/

Zyngier, D. (2008). (Re)conceptualising Student Engagement: Doing Education Not Doing Time. Teaching and Teacher Education: An International Journal of Research and Studies, 24(7), 1765-1776. doi: 10.1016/j.tate.2007.09.004 